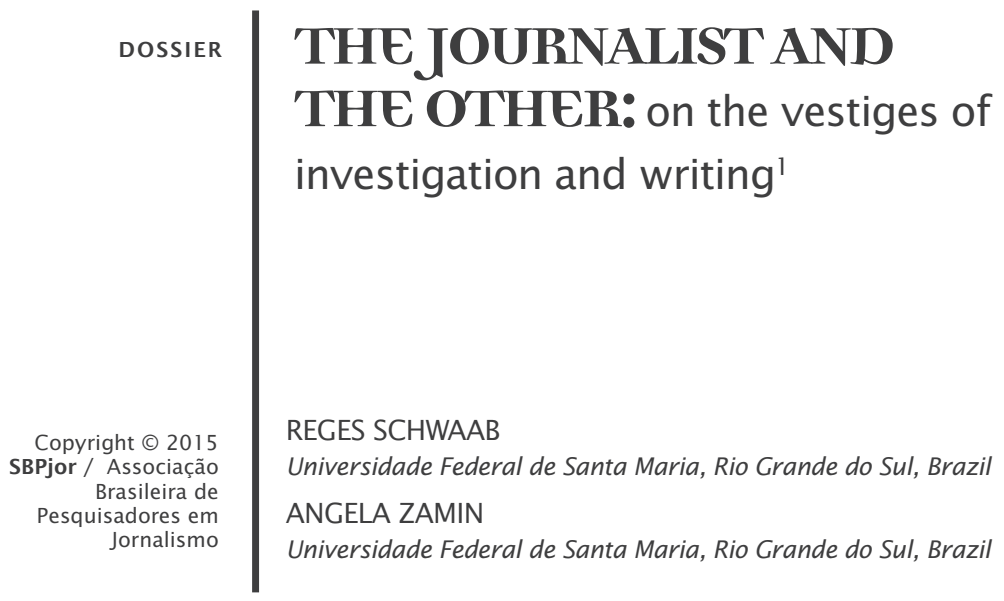

\begin{abstract}
Understanding and writing journalistic narratives as developments in a unique relationship with time itself as well as questioning issues intrinsic to the profession is healthy. The current research examines books written by journalists as a space to pursue such understanding. More broadly, we aim to stress the relationship between media narratives with contemporary issues in a lapsed conceptual space. Thus, our examination takes into consideration three works by Portuguese journalist and writer Alexandra Lucas Coelho: Afghan Notebook (2009), Viva Mexico (2013) and Tahrir! The Days of the Revolution (2011), exploring what they tell us about Journalism and its processes of writing and investigating the concepts of time and of the Other.

Keywords: Narrative. Books written by reporters. Journalistic practices. Alexandra Lucas Coelho.
\end{abstract}

\title{
O JORNALISTA E O OUTRO: sobre os vestígios da sondagem e da escrita
}

RESUMO - Pensar o fazer e o narrar jornalísticos como empreendimentos em singular relação com o próprio tempo e as questões intrínsecas a ele é salutar. O presente texto toma os livros escritos por jornalistas como lugar de fuga para exercitar tal compreensão. A perspectiva mais ampla é a de tensionar a relação da narrativa midiática com as questões do contemporâneo em um espaço conceitual intervalar. Aqui, nosso recorte considera o trabalho da jornalista e escritora portuguesa Alexandra Lucas Coelho em três de suas obras, Caderno Afegão (2009), Viva México (2013) e Tahrir: os dias de revolução no Egito (2011), explorando o que nos dizem sobre o jornalismo e seus processos de apuração e escrita do tempo e do Outro.

Palavras-chave: Narrativa. Livros de repórter. Práticas jornalísticas. Alexandra Lucas Coelho.

\section{EL PERIODISTA Y EL OTRO: sobre los vestigios del sondeo y de la escritura}

RESUMEN - Pensar la forma de hacer y de narrar periodísticamente como emprendimientos en singular relación con el propio tiempo y sus cuestiones intrínsecas es saludable. El presente texto toma los libros escritos por periodistas como lugar de escape para 
ejercitar dicha comprensión. La perspectiva más amplia es la de tensionar la relación de la narrativa mediática con las cuestiones de lo contemporáneo en un intervalo conceptual. Aquí, nuestro recorte considera el trabajo de la periodista y escritora portuguesa Alexandra Lucas Coelho en tres de sus obras, Cuaderno Afegano (2009), Viva México (2013) y Tahrir: los días de revolución en Egipto (2011), explorando lo que nos dicen sobre el periodismo y sus procesos de apuración y escritura del tiempo y del Otro.

Palabras clave: Narrativa. Libros de reporteros. Prácticas periodísticas. Alexandra Lucas Coelho.

\section{OTHER OTHER WORDS}

I do not know who our people are, but my people include Brazilians, Palestinians, Israeli, Afghans, Mexicans, Azoreans or Transmontanos, and it is with all of them that I write, wherever I go (COELHO, 2014, s/p).

The crossroads that characterize reporting practices and allow for something to be said about time and space take shape by supporting itself in the vestiges collected along the way, which permanently rekindles the challenge of thinking about journalistic writing and other possible writings through the need to give an accounting of contemporaneity and its emergences. Therein lies a significant portion of the thing that "inter-ests", to use Bhabha's (2002) expression, in other words, the reflexive movement around a more respectful action for the things of the world.

The narrating action invites us to radically think the interrelationship between the subject and the essence of communication. Thus, the task to walk the paths of journalism "is to find an account of communication that erases neither the curious fact of otherness that is at its core nor the possibility of doing things with words" (PETERS, 1999, p. 21). The situation of interaction and awareness of the perception of the Other "creates a new collective - in the relationship with the other there is not one or the other, but the two taken together"(FRANCE, 2010 , p. 46). There is therefore an inescapable founding element: "the existence of the other's gaze, the unpredictability of the other's intervention and of the possibility/necessity of the subjects to put themselves in each other's place" (FRANÇA, 2010, p. 47).

In the theoretical space interval that such propositions allow, the aim is to explore the relationship between Journalism and questions 
regarding contemporaneity. To this end, we take as conceptual axes the Other, the time and the narrative. In our analysis we consider the work of Portuguese journalist and writer Alexandra Lucas Coelho in three recent book publications - Afghan Notebook (2009), Viva Mexico (2013) and Tahrir: Days of the Revolution (2011) - exploring what these works tell us about journalism practices and processes.

"Journalism was a path that allowed me to bridge the gap between writing and the world, that allowed me to travel and see the world. And to learn to listen to people and learn to look at people" stated the journalist in an interview (COELHO, 2012, p. 158). It was the will to write, fueled by reading, as well as the desire to travel the world that led to periodic reporting. At the time, in 2011 , she reflects, her intent was to go back to books as a production space, since in them it would be possible to realize, more broadly, the complexities of our time. Clues like these can feed the "foundation of possible Other buildings" (Bhabha 2002) to stress journalism as an object.

\section{WRITING AND THE WORLD}

'The race is human/ a week / of God's work" (A raça humana é / uma semana / do trabalho de Deus)". Gilberto Gil's song marks the ending of Afghan Notebook (2010), Alexandra Lucas Coelho to Afghanistan 2008 travel account as special envoy of the Portuguese newspaper Público and of radio RDP, - Antena 1 - and officially published in 2009. Images of the capital Kabul, while in her flight back, merge with the verses by the Brazilian singer and give the last chords of the journalist's attempt to narrate the civilian life that had resisted years of conflict in a privileged way.

In Viva Mexico (2013), originally published in 2010, Coelho goes to southern North America to hear stories that transcend those told by official guides. The time that the author records in this endeavor stems from an experience of what would be, for her, the Mexican time, a cross between the arrival of the conquistadors, violence, fiesta, of human movement recorded in the stones in cathedrals and squares, of anonymous speech, a spinning presentpast "I know nothing about Mexico and I have a backpack" (COELHO, 2013 , p. 19), she states as we open the book. "I know nothing about Mexico ahorita [...], but I have some amulets (COELHO, 2013, p. 22), she concludes after day one. It is a place where everything coexists, records the journalist where the body itself is part of that amalgam. 
Alexandra defines her narrative gesture by the power of the encounter and of the voice that finds a place by locating the potential of the journalistic narrative that fuels itself and allows itself to be affected by the presence of the Other:

\begin{abstract}
That person has a story. So this is a political sense, if we want to have a political sense, it is that there is no me and the other, them and us do not exist, because each person is each person. It's her. And I think this is realized in the movement to go into the world and back. It is realizing this, seeing how, in everyone, there is an entirely worthy and deep history, with lessons and reactions and fears and affection. [...] Journalism tends to perpetuate fictions, reality blurs that are not real; and the attempt that journalism should still practice [...] is exactly to touch the real that is hidden and what is hidden in this blur when people do not stand out. Where people are in the masses, a kind of mortar, they are all the same, or are simply one, a generalization, or Muslims or Jews, slum dwellers. What interests me is to cut each fragment of the image and, with a sort of magnifying glass, to look at it with a sense of context, but with a notion that it is absolutely unique. And this is political. In giving dignity to every person, independently of his or her context, we have to stabilize a whole value, and this is political. This removes from the fiction, the blur (COELHO, 2012, p. 160-161).
\end{abstract}

The reflection registered in this section takes place a few months after the February 2011 experience, still linked to the public's presentation of the book Viva Mexico. It is then that the journalist takes a vacation from Público and goes to Cairo to blend in with the popular movement that had emerged at the beginning of that year, having a public square as place, an experience that resulted in Tahrir: Days of the Revolution (COELHO, 2011). According to the author, the media coverage gives rise to a daily account of the days before, during and after the fall of Hosni Mubarak, fellowship in the square, the tents, of the borrowed internet connection, the endurance and human triumph, in a narrative that wants to capture the political and ethical effect of "dissatisfaction". Alexandra was in Tahrir Square between February fifth and fourteenth of $2011 .{ }^{3}$ Despite the author's caveat that this was not news coverage in the strict sense, the German magazine Lettre International had published part of the text, previous to the book. The social network Facebook was the medium used by the Portuguese to share pictures and comments during the days in Cairo.

\title{
3. ABOUT THE BOOKS
}

By taking books written by journalists as spaces for observation and analysis of the relationship between the narrative, time and space in which it occupies, we take into consideration the notion of "books 
by journalists"4, proposed by Marocco (2001) from two Foucauldian concepts: practice and commentary. According to Foucault (2005, p. 136), the concept of practice is linked to institutional spaces, such as prisons and hospitals, and the discursive practices that originate them, allowing discussions pertaining to dimensions of externality, regularities that organize doing, systems of action. Within this scope we are interested in newspaper's newsrooms. "The rationality of a practice is the open set of multiple historical events - a set in which ways of thinking and ways of doing are tied - that make it acceptable or obvious at one point, that is, by making it exist historically (La racionalidad de una práctica es el conjunto abierto de acontecimientos históricos múltiples - conjunto en que se anudan formas de pensar y formas de hacer - que la hacen aceptable o evidente en un momento dado, es decir, que la hacen existir históricamente) (DE LA HICUERA, 2013, p. XVI-XVII [original emphasis]). Along these lines is the notion of commentary, "the form of repetitiveness and sameness" (FOUCAULT, 2006, p. 29), which the French author locates in religious and legal texts; something Marocco $(2008,2011)$ shifts to the founding journalistic texts, the howto manuals that shape the profession, the journalistic standards.

Objectified as a practice and commentary, the "books by journalists" allow access to journalistic knowledge; to the conditions of possibility on one hand, and to the relations between fields of knowledge, on the other. It is Important to consider that the mediation exercised by Journalism allows you to produce certain knowledge. According to Castro (. 2009, p 394), "Foucault understood knowledge as the boundaries of the relationships between: 1) what can be said in a discursive practice (the domain of objects); 2) the space in which the subject located oneself to talk about the objects (subject positions); 3) the field of coordination and subordination of statements, in which the concepts appear, are defined, applied and transformed; 4) the possibility of usage and appropriation of discourses". The term knowledge, as well as power, has no other role than the methodological, to avoid playing with the perspective of legitimacy occurs with the terms knowledge and domination.

Knowledge points to normative rules that are acceptable at a given moment and in a given field; integrating power relations that cover a range of private mechanisms, definable and defined, made through discourse, through the values that precede the rules of conduct. There is no knowledge without power. 
Power is exercised through networks. Within this net, individuals circulate but are always in a position to repress and produce power; are never the inert or consented target power, are always transmission centers. [...] The individual is an effect of power and at the same time, by means of being an effect, is a transmission center. Power is exercised through the individual constituted by it. (FOUCAULT, 2004, p. 183-184).

It is interesting to counter this perspective with the effort that Foucault himself makes in order for journalism to move from its hegemonic place and to be able to cover the present through another logic In the article Journalism of Ideas (As reportagens de ideias), originally published in November 1978 in the Italian paper Corriere della Sera, Foucault (2008, p. 50) states that we must witness the birth of ideas and the explosion of their strength [...] within the events in which they manifest their strength in the struggles which take place for ideas, or against them. The author signals, along lines Marocco (2008) towards a couple of things: (a) a change in the conception of journalistic source and of their role, and (b) a critique of hegemonic order; consequently, to the knowledge and the set of journalistic practices which, in its interior, oppose one another. The author asserts that, in the contemporary world, ideas explode in a world scale and among minorities or between nations that history has not yet allowed to speak or to be heard ${ }^{5}$ (FOUCAULT, 2008 , p. 50). For such, he experimented with a movement in which journalists and intellectuals, together, worked at the confluence of events and ideas. He experimented with narrative.

Here, the books written by journalist Alexandra Lucas Coelho are discussed from a dual dislocation in relation to Journalism as proposed by Foucault (2008). If journalism assumes, with all its risks, an inescapable commitment to time, to think of the practice and the narration that takes shape through mediated spaces as venture in a unique relationship with time itself and the issues intrinsic to it is salutary. Foucault's inheritance can once again speak to this, in the sense that it allows to work the narrative through a heterotopic production, in search of possible fragments, feeding places and spaces inherent to another type of journalistic writing, completing a circle of understanding on books by journalists. They could be picked up as "other spaces" (FOUCAULT, 2009), places of escape that would allow broadening the understanding of discourse and subjects. For heterotopia, Foucault designates a "possible space", the coexistence of a "large number of possible fragmented worlds" or simply incommensurable spaces that are juxtaposed or superimposed ${ }^{6}$. 
According to Harvey (1996), heterotopia is the appropriate image to capture what fiction generally strives to simply describe. And in the wake of the narrative, the meeting of fiction and journalism is precisely one of the points explored in the study of books written by journalists. ${ }^{7}$ In light of Ricoeur's propositions (2010a; 2010b), with the displacement of his contributions to communication, we can say that journalism is intertwined and takes shape through the inheritance and reconfiguration of aspects of historical and fictional narratives which, in turn, borrow from one another, in the exact sense described by the thinker as the wider field of narrative discourse.

\section{NARRATING AND DOING}

Within shared experience, the narrative investigation, intermittently, time and space, boost the production of new meanings in the hermeneutic circle that gives basis for the action of the subjects. Taking the contemporary as the horizon means that journalism can distend the present in all its times and can relate to other issues, since the act of narration is articulated in the relationship between the world time and lived time (RICOEUR, 2010b). In addition to other modalities of speaking, Journalism can also transpose this time for specific connections that make it malleable. ${ }^{8}$ The narrative is the possibility of discourse extended to action, allowing to talk about things that happen not only in time but also over time, including causes and consequences, although chronologically distant. It is thus the great effect switch that operates on all levels of reality.

Narrative actions, as narrative events, transcend the fact that something happens: They deal with something that is made out of things that happen and that have consequences for the story beings told: According to Pellauer (2013, p. 77), is the fact that the narrated actions create a difference, bring some change to the story being told that suggests we think of them as a point in a sequence. This dimension of the narrative in the communication universe requires depth and empathy with otherness states Peters (1999), requiring an understanding of to what extent are we ready to inevitably face as human what is different.

That is why the dimension of otherness continually presents itself as crucial issue for journalism. As Marcos reminds us (2007), human communication never ceases to be a fact of tension. Its question will always be the Other, a restlessness calling for the 
ending of distance while at the same time constituting itself as a limit to closeness.

In light of this challenge, the act of narration must be seen for its ability to rupture itself, when it interrupts what it had been, when it "opens up the possibility of what is possible" (MARCOS, 2007). The Other remains on the horizon as what is not absolutely clear, infinitely the Other; investigating, narrating and recognizing, however, are inherent and uninterrupted gestures in the mutual comparison of the distance, allowing for frameworks to open up. The reciprocity of the recognition between the subjects is the deepest ethical requirement, or what remains to be thought, giving new meaning to Bhabha (2002, p. 1) proposition's, in a repeated desire to recognize ourselves dually as decentered of the solidarity processes and as conscientious agents of change, which certainly interrogates our objects in a different way.

In journalism, the presence of the Other requires skill, as when it is necessary to dose curiosity and the need to ask about the risks of exposing sources, fact that we see illustrated in some of the subjects that the journalist encounters. For example, this is the case, in the substitution of the names of female Afghan doctors and doulas in order to protect their identity. Additionally, the another example in Afghan Notebooks is the e following: "Amongst these 20 beds in a government hospital there are no conditions to ask you, through a translator, whether your village supports the Taliban and what is your own position" (COELHO, 2010, p. 198). In Viva Mexico, it is the immigrants and refugees gathered in the city of Ixtepec, coming from Guatemala, Belize, Honduras and El Salvador, who synthesize the face of the Other when the journalist is introduced to them:

\footnotetext{
"Today we have here a person who has something in common with you: it is the first time she is in Mexico." They introduce me. "How many of you here are in Mexico for the first time?" They virtually all raise their hands. "Thus, you are already partners in something".

Alejandro Solalinde knows that all these people have reasons to not trust anyone. To explain to them that is the stranger who is taking notes is a form of respect. [...] And so the stranger can become invisible.

We will not be partners, but we have been further from each other. I turn my back because tears fall down my face (COELHO, 2013, p. 283).
}

In Tahrir, the sensitivity in capturing what is beyond words arises, and the encounter with the sources breaks away from the data collection logic. What is the most important requires time, is 
not translated into numbers, as in the dialogue with the 24 years old protester Mahmud:

Pause. He is making an effort to not get emotional. It is the lack of sleep, the constant state of being alert, and the adrenaline to change this own destiny, of suddenly being sovereign.

"We'll be here until death. I'm serious."

As soon as he says this, his eyes are filled with tears, but he continues to look forward, as a young soldier tightening his facial muscles. And the tears are a falling, without a single word. (COELHO, 2011 , p. 21).

The reports emerge from the perception capacity that takes its strength from the characters she meets, but she does not deny them to share the role in the structuring of what to tell: "Revolution is also this: the new face of the Middle East, being Gigi, Fear Obada, Khaled. The West discovering what the Other may be. Moreover, that it enjoyed being the Other (COELHO, 2011, p. 76-77)", she states. Numerous times the gaze towards the journalist as the Other is also present in her work; snippets that reveal not only the ways the work is constructed, but a search for the expansion of its information networks and for the diversity of reports that can make up the reporting experience:

Near 6 pm, a journalist from TV India appears. "Isn't this amazing?" He says, in that version of English that is only spoken in India. But l'm the only one who replies. In these Young people's point of view, India is not Turkey or Brazil, or even posses a Cristiano Ronaldo. Above all things it has stood on the wrong side of politics (COELHO, 2011, p. 60).

I made contact with an 'embedded' in Kandahar, I want to see what the troops do, but also I want to take a trip to Kandahar to be among the Afghans. I imagine Jean [McKenzie] has contacts. (COELHO, 2010, p. 61).

If the newsrooms of the world are checking 'takes' from the Associated Press with the latest news from Kandahar, it was Nur Khan who sent them. He was recommend as the best journalist in the region. I pay him U\$200 for five hours of interpreter-guide from now. I'm not afraid, I'm calm. (COELHO, 2010, p. 221).

The two brothers [Yaqub Ibrahim, 27 years old, and Sayed Parwez Kambakhsh, 23, the Afghan condemned to death], both journalists, wrote articles that have not fallen well between local power groups [...]. Believes that the true cause is political, and that it was mostly their texts that led his brother to be arrested. He had been threatened before. (COELHO, 2010, p. 280).

Yaqub [Ibrahim] expresses himself with great self-confidence. It will not be possible for Afghan journalists to survive otherwise. Several were threatened, fired and even killed. Many of them have been threatened, fired, or even killed. (COELHO, 2010, p.284).

In the days before my arrival it had been worse. Many foreign journalists who tried to enter Tahrir Square became hunting 
prey. The offensive scheme included bloodthirsty appeals in the media, destruction of equipment, detention, and assaults.

An Egyptian journalist was killed (COELHO, 2011 , p. 17).

Upon considering the event as meaningful, in light of a threefold mimesis, (RICOEUR 2010a; 2010b), the narrative establishes the relationship between the world of the author, the text and reader (RESENDE, 2009). And the uniqueness that permeates the journalistic narrative, these broader connections with the particular and the universal (CARVALHO, 2012) emerge as improvers of mediation.

In saying that the "the past is priceless, the present is on credit " (COELHO, 2013, p. 29), when referring to Mexico, the Portuguese journalist points out that the clash between the old and the new world will be a staple of the narrative she is presenting. Her previous experience also appear in the books, adding strength so that the different contexts are fulfilled to the reader and so that points between different spaces and times may be connected. Her trip to Gaza, for example, narrated in Near East (2007), allows for connections with things experienced in Egypt in 2011:

\footnotetext{
The Pyramids are closed and the camels yawn. Can you imagine a million tourists fleeing? This is what happened in Egypt.

But what about this man with his digital camera between the bars of the gate, checking to see if the two largest pyramids fit within the frame?

[...]

"We have been in Egypt for 16 days. We were only going to stay for two weeks, but with this situation we do not know when we will return to my country. "

Which in fact, is not a country.

"We come from Palestine. From Gaza."

Perhaps only a person from Gaza can take pictures of the Pyramids in full state of emergency, for what is a state of emergency for those who only know a state of emergency? (COELHO, 2011, p. 41-42).
}

In the books, we find examples of interpretive work, mediation, making a mutual comparison between the particular and the universal, reiterating the singularities of listening that the Portuguese journalist promotes. At various times, perceptions are bound by it, perhaps in an attempt to capture reflections of the present that erupts:

And everything here is so much less scary since it is the everyday life. Kabul looks dangerous as seen by Europe, later Kandahar seems dangerous seen by Kabul, and later Arghandab looks dangerous seen from Kandahar. And at the end there are always men selling canned drinks, or that have orchards, barefoot men and children trying to live in a country shaken by 
30 years of cold and hot wars (COELHO, 2010, p. 225).

Division is advantageous for Al Qaeda. What I see in Tahrir Square, from the first moment, is the opposite: young people, but also their parents, and grandparents; Muslims but also Christians; religious and secular; rich and poor; illiterate and intellectuals; men and women. On second thought, I believe I had never seen a square that was so much a human microcosm. And that takes place right here in the capital of a world that since September 11 is seen as an enemy of civilization (COELHO, 2011 , p. 20).

Of course, the whole world saw the [Tahrir] Square on television. But now think of half a million people wanting to be a million, and of the sound of that surrounding us. The square is a constantly intertwined canon of songs and slogans, shouts and speeches, appeals and announcements. (COELHO, 2011, p. 24).

And when at last we come to the square [Tlatelolco, Mexico], the extraordinary thing is that we see the three cultures together and each one of them seems to not see the other: the lawn enclosure full of Aztec temples, just below the ground; the colonial church in the background, as if it had just fallen from the sky; the huge square beside it, amidst contemporary buildings.

Three images in the same space, but not at the same time. In European time the buildings add up, in the Mexican time they seem to exist in parallel. Not sequentially, simultaneously. We are the links between them. (COELHO, 2013, p. 92).

The journalist's gaze at places and subjects is built deeper than a mere interview procedure. Alexandra preserves as research sources fictional and nonfictional materials research and nonfiction, from the places she visits. This is how they emerge in her reports, ideas and references to poets, novelists, historians and journalists. Books are not just a method of preparation for work, but take part of the entire process, revealing traces of her investigative methodology of reality.

Thus, the second time I landed in Cairo was in November 2002, with the same suitcase full of Durrell, Kavafis, Forster, Plutarch. (COELHO, 2011, p. 14).

I recognize the names [of places] from travel books. (COELHO, 2010 , p. 21).

Wrote Ibn Nattuta, traveler of travelers, back in the fourteenth century. (COELHO, 2011, p. 13).

I read The Mirage of Peace, the book by Jolyon Leslie and Chris Johnson, the chapter in which they describe the impact of globalization on Afghan culture: TV, pornography, pop music, in a nation that relies on family and relied on the radio to discover the outside world. (COELHO, 2010, p. 277-278).

Leonardo reminds me of a Paz book that I bring with me because it is part of the enlarged edition of El Laberinto de la Soledad, which I stuck in my backpack in Lisbon (COELHO, 2013, p. 37). 
I read Glória Muñoz book about the about the Zapatistas while the screen shoes cartoons about bees, naturally dubbed in Spanish (COELHO, 2013, p. 263).

Octavio Paz describes Mexicans as the loneliest people, perpetually unable to transpose and be transposed. Because of this, and for everything and anything, there is a fiesta. It is an organic need, a discharge. (COELHO, 2013, p. 363).

The examination of on Alexandra Lucas Coelho's work allow us to envision inset space featuring journalism and leads us to other narrative possibilities, something that precisely is materialized through the narrow relationship between journalism with history and fiction, and allow us other narrative possibilities quite themes that are often discussed in the Communication Studies literature ${ }^{9}$ At the same time, rearticulating one of Benjamin's critique (1994) about the loss of traditional narrative to the detriment of informative speech can be fueled by a close listening of those built from the left overs and the remains. To Gagnebin (2013), the "pieces" and the "crumbs" as the object of interest are the representation of the narrative strength coming from vestiges. Despite great speeches, the little things are potent to narratives, something that the books written by journalists, for their double movement and characteristic can shine light on.

In Viva Mexico (2013), Coelho allows time as a possibility for the understanding of a Mexico that she does not find in the everyday journalism approach, or in the official guides. It is a cross between the arrival of the conquistadors, of violence, of the fiesta, the rhythm of the squares, the anonymous street speech:

And when at last we come to the square [Tlatelolco, Mexico], the extraordinary thing is that we see the three cultures together and each one of them seems to not see the other: the lawn enclosure full of Aztec temples, just below the ground; the colonial church in the background, as if it had just fallen from the sky; the huge square beside it, amidst contemporary buildings.

Three images in the same space, but not at the same time. In European time the buildings add up, in the Mexican time they seem to exist in parallel. Not sequentially, simultaneously. We are the links between them. (COELHO, 2013, p. 92).

Octavio Paz referred to them as "three excesses in urban desolation". (COELHO, 2013, p. 92).

When closing the account of the experience in different Mexican regions the author wonders: "Europe is dead, and I am European [...]. Mexico makes you want to cry, a cry of centuries that we do not realize why we cry, if it is we who cry, if we are no longer us, 
but them" (COELHO, 2013, p. 363). And states: "This New World begins with eradication, and this has to mean something. In Indian time it means that eradication is part of the present" (COELHO, 2013, p. 363).

The work is another step in the consolidation of the place that she will build in the type of writing she proposes and, particularly, will give more strength to the book as a space to become the subject of her own work. In Alexandra Lucas Coelho's doing resistance movements of/in journalism emerge in different shades. Her movement takes place especially in the writing of periodic space for others, in which altruism is an inescapable element. Other book publications by the Portuguese writer such as Afghan Notebook (2009) and Tahrir: Days of the Revolution (2011), also allow us to understand more of paths of the journalist subject and his/her writing for the production of difference. This also translates into aspects such as the disassociation of large journalistic institutions, for instance. ${ }^{10}$

In the clash of ideas she promotes, the weight of her choices, her way of viewing journalism and of demarcating the faces that have appeal in her search are not hidden from the readers. "There is rarely something about Mexico in Portuguese newspapers other than the reports from agencies on drug trafficking" (Coelho, 2013, p. 19), she states while flying to North America. Narco trafficking is present in the book, but to the extent of its presence in the population's imaginary and daily life, reflects the author.

According to Coelho (2012, p. 158), the craft of reporting allows her to build a bridge between writing and the world. After years of exercising daily journalism, her steps decided to turn back to books, but now as her main area of production. This is a very relevant and revealing gesture, because the books were, throughout her life, one of the primary training routes, an effective way to see the world before traveling through it (COELHO, 2012).

Undertaking journalism and writing in that way, the singularities of listening to the world that the Portuguese journalist produces are a reflection of a subjectivity that is not masked, as in some areas of journalistic hegemonic practice:

This means fighting to imprint the product of subjective inventions in everyday social relations. And for this, the difficult task of accepting difference as an integral part of life suits us. Difference from which the other in their complex differentiation can exist in a dimension without being reduced to a standardized and universalized compliance (MANSANO, 2009, p. 116).

Viewed in this way, Alexandra Lucas Coelho's book 
productions conforms circuits toward a shared experience, including resistance. The recognition of this effort, unfolding it through the subjects' traces, is an element that is growing within the boarders of journalism practice and reiterates itself for its criticism of the social order, incorporated as an operative trait of her way of doing and narrating journalism.

\title{
5. WHAT IS LEFT
}

\begin{abstract}
Don't ever by a Mexican Routard Guide at the Charles de Gaulle airport. For example, what the Routard has to say about Tlatelolco - the square that became the Tiananmen of Mexican students is that if we are counterrevolutionaries this is an expendable square. French people, nothing personal drives me against you, but Tlatelolco is one of the most fascinating places in Mexico City, whether we are revolutionaries, counterrevolutionaries or trapeze artists. (COELHO, 2013, p. 91).
\end{abstract}

Embeding events with their historical and unique character is to allow to place them in the temporality of significance, states Bhabha $(1998,2002)$. So it can be for journalism. By narrating, we are able to prevent subjects and events to be obliterated by a "chain of events" or by a determining ontology of "causes" in the true testimony of what is "left" to the overall story, reiterates the thinker.

Since the relationship between subjects is the key question of Communication inquiry, the stature that it requires must be made without fear. The Other as the first commitment and as a perspective for the production of journalistic knowledge is undoubtedly a characteristic of the current historical moment and of the objects that characterize it, especially in trying to discuss different ways of thinking in contemporary journalism.

If we consider the characteristics of the books by journalists - taking into account our previous analysis, we can understand that the processes of investigation and writing of the time and of the Other are nothing but practical objectives in a practical sense of the use of language, that is, the journalistic character is maintained and reaffirmed in the detailed work that the book allows. At the same time, the book becomes "other space" to the narrative since the journalist explicitly reveals their presence, their choices and their paths in the unraveling of events.

As her role as agent stands out, is not masked to other social actors that their role can also be taken into perspective, since the 
displacement of periodic journalism to the book happens without the everyday constraints of the journalistic practice. In another thickness, the book's pace enables say more scenic, but also requires the exercise of the synthesis happened. This recovery, however, calls for a gathering of traces and sayings, excited by the possibility that more extended relationships can be established. Through a different density, the book's pace enables a more panoramic telling, but also requires the exercise of the synthesis of what took place. This recovery, however, calls for a gathering of vestiges and sayings, fuelled by the possibility that more extended relationships can be established.

\section{Notes}

1 Revised version of the paper presented at the $12^{\circ}$ Encontro da Associação Brasileira de Pesquisadores em Jornalismo - SBPJor.

3 The term "Other", with a capital "O" is used in the Marcos (2008) work, to argue that the right of every human being is the ability to be recognized as such, in its absolute and radical otherness. The thinker borrows from Emmanuel Levinas's propositions regarding an Other as the linchpin of action and reflection; the subject decentralizes from himself, of his/her sameness. As the author reminds us, the most valuable human relationships are those that interrupt something, that do not leave us indifferent, but that disturb our identity. However, within the quotes, we kept the spelling adopted by the authors.

4 The Arab Spring in Egypt began on January 25, 2011 ; on February 1 , more than a million people gathered in Tahrir Square in Cairo. On February 11, Mubarak resigned as president of the country.

5 Usually the study of books written by journalists is marked, nonconsensually as guided by notions of romance stories, literary journalism, literature, narrative journalism, new journalism and gonzo journalism. Here, however, the books are taken by the concept of "books by journalists" (MAROCCO, 2011) precisely because they transcend the character of a longer story. Beyond the stories, these books deal critically with journalism itself, as explained in the article

Translated from Portuguese.

7 Translated from Portuguese 
8 For example Schneider work (2013), exploring the "dirty fictions", comparing the story-novel reporting-book and the combination of journalistic investigation techniques and stylistic features of literature.

9 Ricoeur does not write about the media and journalism, it is regarding a tentative look back of the mass communication field.

10 Ricoeur (2010c) sees time as something human, fruit of the action and the suffering in the story told. In the case of the History discipline, human time can be related to the historical period, which is placed between the lived time and cosmic time by inscribing one in the other. As far as fiction, it allows the perception of how the narrative resets the time. The novel's narrative variation for example, extends the social sphere in which the action unfolds to give attention to ordinary people, with emphasis on social and psychological complexity, providing a greater understanding of the world.

11 This statement does not invalidate the possibility that in the so-called traditional spaces, the journalistic practice can develop in terms of what we have discussed. It is undeniable, however, that the book presents itself as an ideal place for such.

\section{References}

BENJAMIN, Walter. Magia e técnica, arte e política: ensaios sobre literatura história da cultura. São Paulo, Brasiliense, 1994.

BHABHA, Homi. Democracia des-realizada. Revista Tempo Brasileiro, Rio de Janeiro, n. 148, p. 67-80, jan./mar. 2002.

BHABHA, Homi. O local da cultura. Belo Horizonte: UFMG, 1998.

CARVALHO, Carlos A. Entendendo as narrativas jornalísticas a partir da tríplice mimese proposta por Paul Ricoeur. Matrizes, São Paulo, v. 6, n. 1-2, 2012. Disponível em: <http://www.matrizes.usp.br/index.php/ matrizes/article/view/261>. Acesso em: 5 jan. 2015.

CASTRO, Edgardo. Vocabulário de Foucault. Um percurso pelos seus temas, conceitos e autores. Belo Horizonte: Autêntica, 2009.

COELHO, Alexandra Lucas. Caderno Afegão. Um diário de viagem. Lisboa: Tinta da China, 2009.

COELHO, Alexandra Lucas. Corta-e-cola até à derrota final. Atlântico Sul, blog. 2014. Disponível em: <http://blogues.publico.pt/atlanticosul/2014/07/27/corta-e-cola-ate-a-derrota-final>. Acesso em: 5 jan. 2015. 
COELHO, Alexandra Lucas. Tarhir: os dias da revolução no Egito. Rio de Janeiro: Língua geral, 2011.

COELHO, Alexandra Lucas. Uma ponte entre a escrita e o mundo (entrevista). In: MAROCCO, Beatriz. O jornalista e a prática - entrevistas. São Leopoldo, RS: Ed. Unisinos, 2012, p. 157-179.

COELHO, Alexandra Lucas. Viva México. Rio de Janeiro: Tinta-da-china Brasil, 2013.

DE LA HIGUERA, JAVIER. Estudio Preliminar. In: FOUCAULT, Michel. Sobre Ia ilustración. 13. reimp. Madrid: Tecnos, 2013. p. IX-LXVII.

FOUCAULT, Michel. A arqueologia do saber. 7. ed. Rio Janeiro: Forense Universitária, 2005.

FOUCAULT, Michel. A hermenêutica do sujeito. São Paulo: Martins Fontes, 2004.

FOUCAULT, Michel. A ordem do discurso. 14. ed. São Paulo: Edições Loyola, 2006.

FOUCAULT, Michel. As reportagens de ideias. In: BERGER, C.; MAROCCO, B. Ilha do Presídio: uma reportagem de ideias. Porto Alegre: Libretos, 2008. pp-49-51.

FOUCAULT, Michel. Estética: literatura e pintura, música e cinema. 2 ed. Rio de Janeiro: Forense Universitária, 2009. (Ditos e Escritos, III).

FOUCAULT, Michel. Mesa redonda em 20 de maio de 1978. In: Estratégia, Poder-saber. Rio Janeiro: Forense Universitária, 2010. p. 335-351.

FRANCA, Vera. Impessoalidade da experiência e agenciamento dos sujeitos. In: LEAL, Bruno Souza; GUIMARÃES, César; MENDONÇA, Carlos (orgs.). Entre o sensível e o comunicacional. Belo Horizonte: Autêntica, 2010, p. 39-54.

GAGNEBIN, Jeanne Marie. História e narração em Walter Benjamin. 5 reimpr. 2 ed. São Paulo: Perspectiva, 2013.

HARVEY, David. Condição pós-moderna. São Paulo: Loyola, 1996.

MANSANO, Sonia R. V. Sujeito, subjetividade e modos de subjetivação na contemporaneidade. Revista de Psicologia da UNESP, v. 8, n. 2, 2009. p. 110-117. Disponível em:<http://www2.assis.unesp.br/revpsico/index. php/revista/article/viewFile/139/172>. Acesso em: 5 jan. 2015.

MARCOS, Maria Lucília. Princípio da relação e paradigma comunicacional. Lisboa: Colibri, 2007.

MAROCCO, Beatriz. Os "livros de repórter", o "comentário" e as práticas 
jornalísticas. Revista Contracampo, Niterói, n. 22, fev. 2011 , p. 116-129. (Programa de Pós-Graduação em Comunicação). Disponível em: <http:// www.uff.br/contracampo/index.php/revista/article/view/86/67>. Acesso em: 5 jan. 2015.

MAROCCO, Beatriz. Reportagem de transgressão, um giro no tratamento da fonte jornalística. In: BERGER, C.; MAROCCO, B. Ilha do Presídio: uma reportagem de ideias. Porto Alegre: Libretos, 2008. p- 33-47.

PELLAUER, David. Ações narradas como fundamento da identidade narrativa. In: NASCIMENTO, Fernando; SALLES, Walter (orgs.). Paul Ricoeur: ética, identidade e reconhecimento. Rio de Janeiro: Ed. PUC-Rio; São Paulo: Loyola, 2013. p. 57-79.

PETERS, John D. Speaking in the air - a history of the idea of communication. Chicago: The University of Chicago Press, 1999.

RESENDE, Fernando. O jornalismo e suas narrativas: as brechas do discurso e as possibilidades do encontro. Galáxia, São Paulo, n. 18, p. 31-43, dez. 2009. Disponível em: <http://revistas.pucsp.br/index.php/ galaxia/article/view/2629>. Acesso em: 5 jan. 2015.

RICOEUR, Paul. Tempo e narrativa. v. 1. São Paulo: WMF Martins Fontes, $2010 a$. (A intriga e a narrativa histórica).

RICOEUR, Paul. Tempo e narrativa. v. 3. São Paulo: WMF Martins Fontes, 2010b. (O tempo narrado).

SCHNEIDER, Sabrina. Ficções sujas: por uma poética do romancereportagem. Tese. (Doutorado em Letras). Pontifícia universidade Católica do Rio Grande do Sul. Porto Alegre, 2013.

Reges Schwaab is a journalist and a professor at Universidade Federal de Santa Maria - Campus Frederico Westphalen (UFSM). He holds a PhD in Communication and Information from the Universidade Federal do Rio Grande do Sul (UFRGS). E-mail: reges.ts@gmail.com.

Angela Zamin is a journalist and a professor at Universidade Federal de Santa Maria - Campus Frederico Westphalen (UFSM). She holds a PhD in Communication Sciense from the Universidade do Vale do Rio dos Sinos (UNISINOS). E-mail: angelazamin@gmail.com.

RECEIVED ON: 26/02/2015 | APPROVED ON: 15/04/2015 